\title{
POTENTIAL USE OF VIRTUAL CURRENCIES IN MONEY LAUNDERING AND TERRORISM FUNDING IN INDONESIA
}

\author{
Hakim Sapoan*, Akram, Husnan Lalu Hamdani \\ Master of Accounting Program, Mataram of University, Indonesia \\ ${ }^{*}$ E-mail: sapoan.hk@gmail.com
}

\begin{abstract}
Virtual Money emerge as payment instruments in recent years. Based on the report of the Indonesian NRA Team in 2015, virtual currecy such as Bitcoin consider as Tindak Pidana Pencucian Uang (TPPU) emerging threat because the use of Bitcoin in Indonesia has been developed as an alternative payment of property transactions, luxury vehicles, beverage and accommodation. The aim of this study is to analyze the potential use of virtual currency in money laundering and financing terrorism in Indonesia. The absence of regulatory and oversight authorities, the use of vulnerable virtual currency is used for illegal transactions, money laundering and terrorism financing. The conditions of such transactions can open up opportunities for fraud and crime in various forms that can harm society. In addition to the virtual currency that has a vagueness underlying asset for its value, speculative virtual currency transactions can pose a risk of bubble that not only harms the public but also potentially disrupts the stability of the financial system.
\end{abstract}

\section{KEY WORDS}

Virtual currency, money laundering, terrorism funding, Indonesia.

Along with the development of science and technological advances that exist today has changed the lifestyle of society, one of them in the field of business transactions. At this time business transactions no longer require sellers and buyers to meet face to face and use cash money to conduct a business transaction, now business transactions can be done using the facilities of the virtual world or the internet. Internet (interconnection networking) is the name for a set of computer networks that connect academic sites, government, commercial, organizations, and individuals. The Internet provides access to telecommunications services and information resources to its millions of users that spread all over the world (Butarbutar, 2014).

Virtual Money emerge as payment instruments in recent years, there are many terms used to call it ie: Digital Currency, Virtual Currency, Crypto Currency and others. This virtual money is money that circulate in Cyberspace. This virtual money applies universally and does not follow certain countries' currencies and the virtual money market is on demand from its users so that the exchange rate of this virtual money is very volatile and tends to be unstable. Virtual money is considered special because the virtual money is actually does not have anyform and not real.

One of the virtual money that circulating in Indonesia is Bitcoin. Bitcoin is a peer-topeer implementation of the proposal (b-money) by Wei Dai and Nick Szabo's Bitgold proposal. The principle of the system in general has been described in 2008 by Satoshi Nakamoto. Someone who participates in a bitcoin network has a wallet that stores some keystroke keypair.

But Bitcoin according to the Financial Action Task Force (FATF) report may pose a risk of money laundering and illegal expenditure such as for drug transactions, terrorism financing, or illegal (illegal) arms purchases. This risk arises because the use of bitcoin for anonymous transactions for illegal expenditure will be extremely difficult to trace. The FATF notes that the virtual currency has "attracted the attention of various criminal groups", including extremist organizations. Furthermore, the FATF in its report presents a number of interesting cases, but the actual prevalence and extent of exploitation of this technology by 
terrorist groups and their supporters has not been very clear at this time and the ongoing information gap will continue to be explored.

According to Sarah N. Welling, money laundering begins with the existence of "illicit money" or "dirty money". (Sutedi, 2008) Money can get dirty in two ways, first, through tax evasion that is obtaining money legally, but the amount reported to the government for tax purposes is less than actually earned. And the second is to earn money through unlawful means, such as the sale of drugs or illegal drug trafficking, gambling, bribery or corruption, terrorism ), prostitution, arms trafficking, smuggling of alcohol, tobacco, pornography, smuggling of contraband alcohol, smuggling of people, and white collar crime ). (Sutedi, 2008)

Money laundering practices are initially made only for money earned from drug trafficking and similar drugs (illegal drugs) or known as illegal drug trafficking. But then, money laundering is made against money earned from other sources of crime as mentioned above. In fact, an internationally funded source of money derived from drug trafficking is not the main one. The main portion of the illicit money comes from tax evasion, flight capital, and irregular or hidden economies that are distinguished from the overly criminal economies. (Perbawa, 2015)

Flight capital includes flight capital for money provided by developed countries in the form of financial aid, which is not spent or invested in the country concerned, but then returned to developing countries such as illegal exported capital. This money is often placed in foreign banks that actually have given credit.

Based on the report of the NRA Indonesian Team in 2015, virtual currency such as Bitcoin is an emerging threat of Tindak Pidana Pencucian Uang (TPPU) because the use of Bitcoin in Indonesia has been developed as an alternative payment of property transactions, luxury vehicles, beverage and accommodation. In fact, in some locations in Indonesia has been available several ATM Bitcoin outlets. Bitcoin is also proven to be used in the transaction of buying and selling customer data online.

The aim of this study is to analyze the potential use of virtual currency in money laundering and financing terrorism in Indonesia

\section{RESULTS AND DISCUSSION}

A virtual currency or virtual money has been defined in 2012 by the European Central Bank as "a type of unregulated, digital money, which is issued and usually controlled by its developers, and used and accepted among the members of a specific virtual community. In 2014, the European Banking Authority defined virtual currency as "a digital representation of value that is neither issued by a central bank or a public authority, nor necessarily attached to a fiat money or currency, but is accepted by natural or legal persons as a means of payment and can be transferred, stored or traded electronically" (Zahudia and Amir, 2016)

VCs are digital representations of value, issued by private developers and denominated in their own unit of account. VCs can be obtained, stored, accessed, and transacted electronically, and can be used for a variety of purposes, as long as the transacting parties agree to use them. The concept of VCs covers a wider array of "currencies," ranging from simple IOUs of issuers (such as Internet or mobile coupons and airline miles), VCs backed by assets such as gold, and "cryptocurrencies" such as Bitcoin.. (Dong He et al, 2016).

As digital representations of value, VCs fall within the broader category of digital currencies (Figure 1). However, they differ from other digital currencies, such as e-money, which is a digital payment mechanism for (and denominated in) fiat currency. VCs, on the other hand, are not denominated in fiat currency and have their own unit of account (Dong He et al, 2016).

VC schemes comprise two key elements: (i) the digital representation of value or "currency" that can be transferred between parties; and (ii) the underlying payment and settlement mechanisms, including the distributed ledger system. VC schemes have different levels of convertibility to real-world goods, services, national currencies, or other VCs. Non- 
convertible VCs (or closed schemes) operate exclusively within a self-contained virtual environment. Under these systems, the exchange of VCs with fiat currency (or other VCs) or its use in payments for goods and services outside of the virtual domain is significantly restricted. In contrast, convertible VCs (or open schemes) allow for the exchange of the VC with fiat currency (or other VCs) and for payments for goods and services in the real economy. The level of contact between convertible VCs and the real economy is much greater than is the case in closed schemes (Dong He et al, 2016).

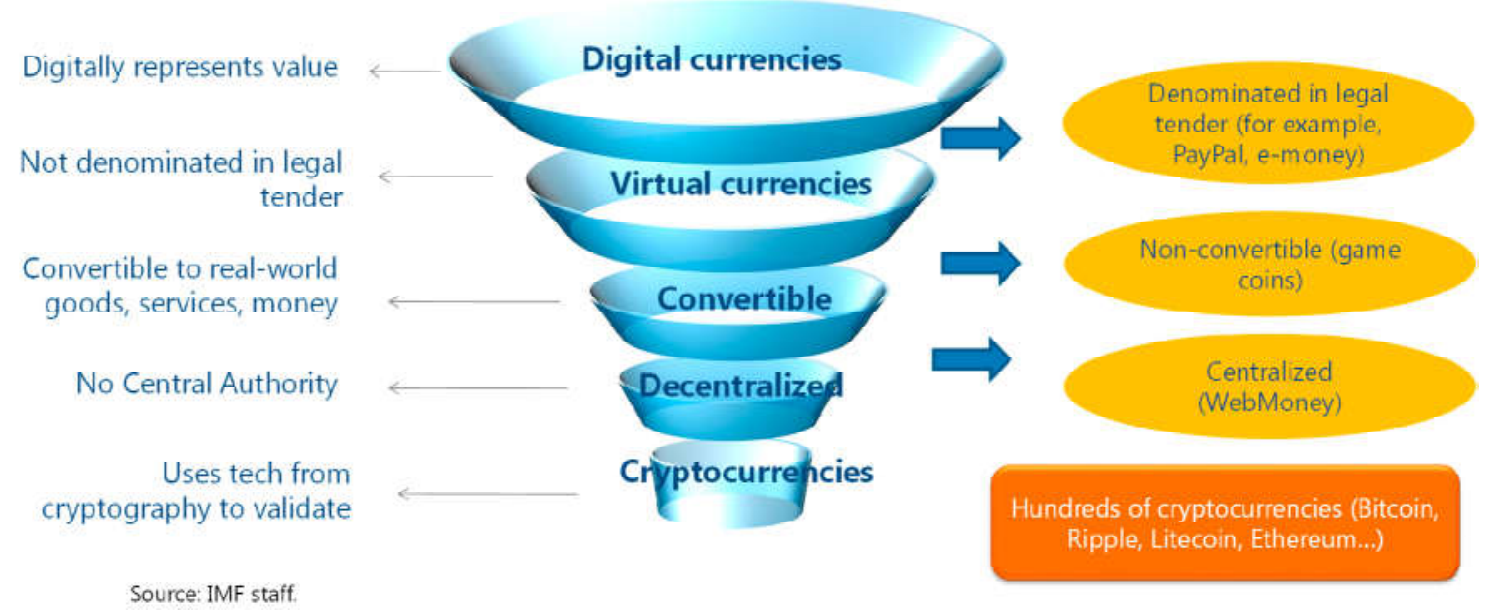

Figure 1 - Virtual Currency (Dong He et al, 2016)

Virtual money has several advantages that are (1) Security, unlike conventional counterfeit currency, the cryptographic rules applied to bitcoin keep their owners protected from the same risks. (2) As a global currency, even though each country has its own currency, virtual money remains present and enters it. Virtual money knows no national borders, does not waver due to political conditions in government, and is not affected by anything. (3) As a protector of inflation, the gold of virtual money is considered to be a protected value of inflation that can suppress excessive inflation. (4) As a Savings, virtual money is a new form of community savings that is applied with a system that is not troublesome. In addition to saving virtual money, all the usual financial intermediaries in banks can be eliminated. The holders also do not need to pay service fees and registration.

In the midst of these advantages, Virtual Money was also saved a number of major weaknesses, such as (1) Unstable, virtual money is a currency that is speculative. While there are not enough companies currently offering the purchase and sale of products with virtual money as a means of payment. (2) Very risky lost or stolen, as virtual currency, virtual money is stored in the form of digital file or known as wallet file. But wallet files stored on hard disk electronic equipment are very vulnerable to damage. In addition, the virus that attacks the hard disk can also make the virtual money stored vanish just like that. The digital wallet can also be hacked and stolen through malware.

The result of risk assessment of terrorism crime by the National Risk Assessment Team (NRA) of Indonesia showed that high-risk terrorism funds is transfered through electronic payment system, online payment system, system or New Payment Method, through business activities ; through jewelers / gold and motor vehicles; through the activities of foreign exchange exchange and through the carrying of cash both domestically and across national borders from and abroad by terrorist network (courier) including high risk transaction pattern in Indonesia.

Pusat Pelaporan Dan Analisis Transaksi Keuangan (PPATK) in the 2015 annual report states that the national risk assessment of the Terrorism Financing Crime (TPPT) resulted in several risk mapping including high-risk terrorism financing modes using domestic financing through donations to foundations, misuse of foundations, trading / business activities, as well as through criminal activity. The high-risk perpetrator profile of the individual is the student / 
student and for the corporation / entity actors is the non profit organization (NPO). There are 9 (nine) regions that are at high risk of terrorism financing such as DKI Jakarta, West Java, Central Java, Banten, North Sumatra, Nanggroe Aceh Darusalam, South Sulawesi and NTB.

Executive Director of Policy and Supervision Department of BI Payment System Eni Panggabean explained, the current number of virtual currency that reached 1,400, one of them is bitcoin. The bitcoin is one of the largest virtual currency market capitalization. In addition to bitcoin, there is also ethereum, ripple, bitcoin cash, cardano, NEM, litecoin, and so on. According to $\mathrm{BI}$ data, the current market capitalization bitcoin reached 246 billion US dollars. The market capitalization of ethereum and ripple is 133 billion and 79 billion US dollars respectively. Thus, until January 13, 2018, total market capitalization of virtual currency has reached 752.542 billion US dollars. The figure is based on data from CoinMarketCap at http://ekonomi.kompas.com/read/2018/01/15/155246226/ingat-matauang-virtual-tak-hanya-bitcoin

Below are the dinamics of Bitcoin price in last year.
\begin{tabular}{|l|l|l|l|l|l|l|l|}
\hline $1 \mathrm{~h}$ & $12 \mathrm{~h}$ & $1 \mathrm{~d}$ & iw & $1 \mathrm{~m}$ & $3 \mathrm{~m}$ & $1 \mathrm{y}$ & All \\
\hline
\end{tabular}
$\operatorname{Jan} 29,2017$ to $\operatorname{Jan} 29,2018$

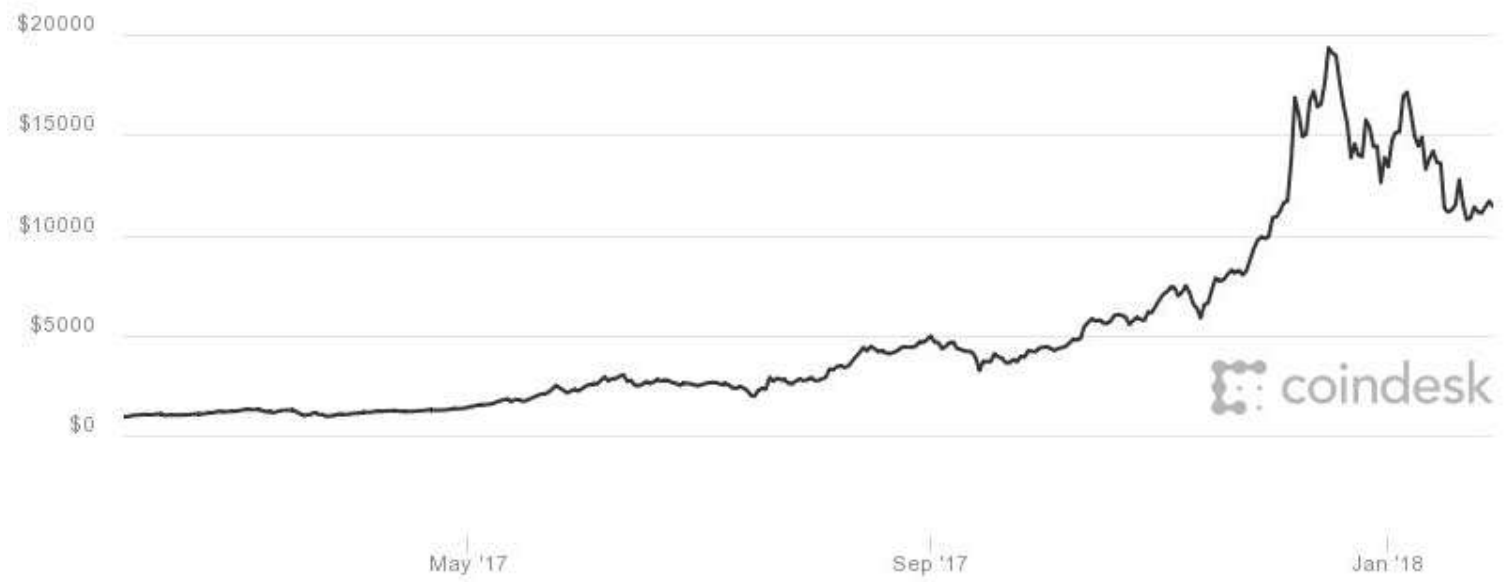

Figure 2 - Bitcoin international price chart (January 29, 2017 - 29 january 2018) Source: coindesk.com

Until January 29, 2018 the price of bitcoin in the international market is USD 11,694.47. While in Indonesia, bitcoin price at the same time is Rp 155.999.000. Lowest price Rp. $6,000,000$ the highest price of $\operatorname{Rp} 297,575,000$ rose about $1,161.67 \%$ in the past year.

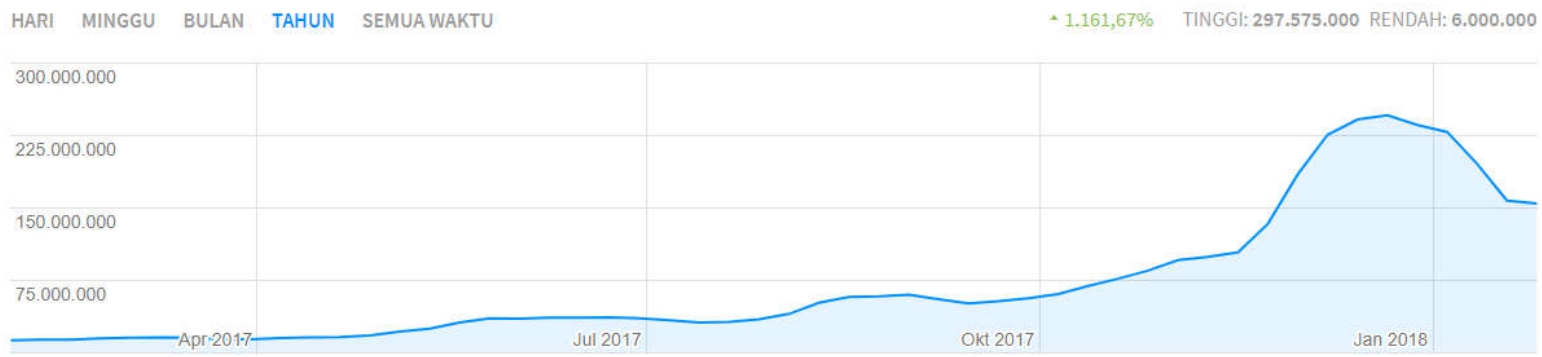

Figure 3 - Bitcoin price in indonesia (29 January 2017- 29 January 2018) Source luno.com

The results of Sean Foley et al (2018) research sshowed that 44 percent of bitcoin transactions and 25 percent of bitcoin users were associated with illegal activities. Their findings since April 2017 show that some 24 million bitcoin market participants use the virtual 
currency specifically for illegal purposes. Bitcoin users are estimated to make 36 million transactions per year. The transaction value reached the range of 72 billion US dollars. Collectively, the researchers added, they have bitcoin with a value of 8 billion US dollars. One of the reasons bitcoin is so popular among criminals is that this virtual currency allows users not to use their real identity. However, transactions are not entirely anonymous, because every transaction is recorded by blockchain.

Indonesian Finance Minister Sri Mulyani stated that the Government urges people not to use virtual currency or bitcoin in trade and investment transactions. Because as a Bitcoin investment there is no basis and therefore prone to the use of the instrument for money laundering and terrorism financing.

This is reinforced by the Press Release of the Ministry of Finance of the Republic of Indonesia in January 22, 2018 concerning the Warning of the Use of Virtual Currency in Indonesia. That due to the development of virtual currency (cryptocurrency) based on distributed ledger technology, such as Bitcoin, which increasingly prevalent has become the attention of various world financial authorities given the enormous potential risks, not only to the user community but also its impact on the stability of the financial system. Observing the matter and the various polemics that accompany it, the Ministry of Finance hereby affirms that:

1. The use of virtual currency as a transaction tool to date has no formal basis. Referring to Act No. 7 of 2011 concerning Currency, it is affirmed that the currency is money issued by the Unitary State of the Republic of Indonesia and any transactions that have a purpose of payment, or other obligations that must be met with money, or other financial transactions conducted in the territory of the Unitary State of the Republic of Indonesia shall use the Rupiah. Therefore, the Ministry of Finance supports the policy of Bank Indonesia as the monetary authority and payment system for not recognizing the virtual currency as a valid payment instrument, so it is prohibited to be used as a legal means of payment;

2. Given the absence of regulatory authority and oversight, the use of virtual currency is prone to illegal transactions, money laundering and terrorism financing. The conditions of such transactions may open up opportunities for fraud and crimes of any kind that could harm the public; and

3. In addition to the risks arising from owning and / or trading virtual currencies that have uncertain underlying asset values, speculative virtual currency transactions may pose a risk of bubble that not only harms the public but also potentially disrupts the financial system stability.

But the virtual currency, especially Bitcoin already circulating in Indonesia and used in transactions. Bank Indonesia representative of Bali province office identified 44 businesses in the local area receiving virtual currency in transactions, among them using bitcoin. The Head of Bank Indonesia Representative of Bali Province, Causa Iman Karana, explained that 44 of them are engaged in hotel business, vehicle rental services, cafes, and tour packages. The results, obtained after the team from Bank Indonesia Representative of Bali Province, conducted a survey to a number of locations based on information from the community and information that develops in social media.

The central bank curently gives a warning in the form of reprimands and remind the business actors not to use virtual currency as a payment system anymore. But if they still found to do the practice, then the police will arrest them. Bitcoin, is one of the top five virtual currencies in the world such as ethereum, ripple, bitcoin cash, and cardano from a total of about 1,300 digital currencies.

Bank Indonesia has banned the virtual currency because it is not recognized as a valid payment instrument in Indonesia in accordiance to Act No. 7 of 2011 concerning Currency. In that rule, the currency is the money issued by the Negara Kesatuan Republik Indonesia and any transactions that have the purpose of payment or other obligations that must be pay with money, or other financial transactions conducted in the territory of the NKRI must use the Rupiah. BI thinks the virtual currency is risky and full of speculation because no authority is responsible for it, there is no official administrator, there is no basis underlying the price of 
the virtual currency and the value of trade is very volatile. As a result, vulnerable to risk inflation and prone to be used as a means of money laundering and financing of terrorism so as to affect the stability of the financial system and harm the public.

\section{CONCLUSION}

The absence of regulatory authority and oversight make the use of virtual currency vulnerable to be used for illegal transactions, money laundering and terrorism financing. The conditions of such transactions can open up opportunities for fraud and crime in various forms that can harm society. In addition to the virtual currency that has a vagueness considering underlying asset for its value, speculative virtual currency transactions can pose a risk of bubble that not only harms the public but also potentially disrupts the stability of the financial system.

\section{REFERENCES}

1. Abimanyu, Bambang, 2005, Teror Bom di Indonesia, Jakarta: Grafindo.

2. Arens, Alvin A., Randal J., Elder. Mark S. Beasley. 2012. Auditing and Assurance Service: An Integrated Approach. Edisi Empat Belas. Jakarta: Erlangga.

3. Arifin. 2005. Teori Keuangan dan Pasar Modal. Yogyakarta: Ekosinia.

4. Ashley, Sean Paul, 2012. The Future of Terrorist Financing: Fighting Terrorist Finaincing in Digital Age, Penn State Journal of Internatlonal Affairs 2 (1, Spring) 2012 pp.9-26.

5. Babbie, 2010. The Practice of Social Research. Wadsworth: Cengange Learning

6. Bazeley, Patricia., 2007. Qualitative Data Analysis with Nvivo, SAGE Publications Ltd.

7. Bell, J. 2008. Terrorism: Some observations, Journal Terrorism Vol. 3, 1980 - Issue 3-4.

8. Bombace, Michael, 2013. Blazing Trails: A New Way Forward for Virtual Currencies and Money Laundering. Journal of Virtual Worlds Research Vol. 6, No. 3 Sep. 2013.

9. Brigham, Eugene F dan Houston, Joel F. 2013. Dasar-Dasar Manajemen Keuangan. Edisi 11 Buku 2 Jakarta: Salemba Empat.

10. Butarbutar, 2014 Tinjauan Yuridis Cybercrime Terhadap Fidusia Online Di Indonesia, Lex et Socetatis, Jurnal Universitas Samratulangi, Volume 2 Nomor 4, 2014, hlm 5.

11. Choo, Kim-Kwang Raymond, Slay, Jill, Lui, Lin \& Irwin, Angela SM 2014 'Money Laundering And Terrorism Financing In Virtual Environments: a feasibility study', Journal of Money Laundering Control, vol. 17, no. 1, pp. 50-75.

12. Connelly, Brian L. S., Trevis Certo, R. Duane Ireland, 2011. Signalling Theory: a Review and Assesment. Journal of Management Vol 37, Issue 1, 2011.

13. Danim, Sudarwan dan Darwis, 2003. Metode Penelitian. Jakarta:Pustaka Pelajar.

14. Dong He, Karl Habermeier, Ross Leckow, Vikram Haksar, Yasmin Almeida, Mikari Kashima, Nadim Kyriakos-Saad, Hiroko Oura, Tahsin Saadi Sedik, Natalia Stetsenko, and Concepcion Verdugo-Yepes, 2016. Virtual Currencies and Beyond: Initial Considerations. IMF Staff Discussion Notes No. 16/3 January 20, 2016.

15. Financial Action Task Force (FATF), 2015. Emerging Terrorist Financing Risks, FATF report of October 2015.

16. Fromkin, Victoria and Robert Rodman,2001, An Introduction to Language, Fifth Edition, Harcourt Brace Jovanovich College Publisher.

17. Garnasih, Yanti, 2003. Kriminalisasi Pencucian Uang (Money Laundering). Universitas Indonesia, Jakarta.

18. Irwin, Angela S M and Jill Slay, 2010. Detecting Money Laundering and Terrorism Financing Activity in Second Life and World of Warcraft. International Cyber Resilience conference Conferences, Symposia and Campus Events Edith Cowan University, Perth Western Australia, 23rd August 2010.

19. Joshi, Tulip, 2016. Virtual Path From Black To White: Money Laundering Made Easy. International Journal Of Legal Insight Volume I, Issue 2 | ISSN: 2456-3595. 
20. Johnstone, Karla M., Audrey A. Gramling, Larry E. Rittenberg. 2014. Auditing: A RiskBased Approach to Conducting A Quality Audit. Edisi Sembilan. South Western Cengange Learning: USA.

21. Karyono. 2013. Forensic Fraud. Yogyakarta: ANDI.

22. Kurniawan, 2013. Perkembangan Tindak Pidana Pencucian Uang (Money Laundering) Dan Dampaknya Terhadap Sektor Ekonomi Dan Bisnis. Jurnal Ilmu Hukum Vol. 3 No. 1.

23. Liu, Lin, Choo, Kim Kwang \& Irwin, Angela Samantha Maitland 2012 'An analysis of money laundering and terrorism financing typologies' Journal of money laundering control, vol. 15 , no. 1 , pp. 85-111.

24. Manullang. A.C., 2001. Menguak Tabu Intelijen: Teror, Motif dan Rezim. Jakarta.

25. McKinney, R. E., Shao, L. P., Shao, D. H. \& Rosenlieb, D. C., 2013. The reality of digital currency as a financial medium of exchange. Journal of International Finance Studies 13(3), 45-50.

26. Moleong, 2007. Metodologi Kualitatif Edisi Revisi. Bandung: PT Remaja Rosdakarya.

27. Muladi, 2002. Hakekat Terorisme dan Beberapa Prinsip Pengaturandalam Kriminalisasi, Jurnal Kriminologi Indonesia FISIP UI,Vol 2 no III.

28. Nasution, S. 1988. Metode Penelitian Naturalistik Kualitatif. Bandung: Tarsito.

29. Nazir, Moch. 2003, Metode Penelitian, Salemba Empat, Jakarta.

30. Perbawa, Ketut Sukawati Lanang Putra, 2015. Tindak Pidana Pencucian Uang Dalam Sistem Perbankan Indonesia, Jurnal Advokasi Vol. 5 No.1 Maret 2015.

31. Pflaum, Isaac And Emmeline Hateley, 2014. A Bit Of A Problem: National And Extraterritorial Regulation Of Virtual Currency In The Age Of Financial Disintermediation, Georgetown Journal of International Law 45.1169 (2014).

32. Priantara, Diaz. 2013. Fraud Auditing \& Investigation. Jakarta: Mitra Wancana Media.

33. Purwadi, Ari, 2012. Jasa Private Banking Pada Lembaga Perbankan Sebagai Sasaran Dan Sarana Pencucian Uang, Jurnal Perspektif Vol 17, No 1 (2012).

34. Robinson, 2004. Mewaspadai Pencucian Uang Melalui Pasar Modal, dalam Jurnal Hukum Bisnis, vol. 22 No. 3, Yayasan Pengembangan Hukum Bisnis, halaman 55.

35. Sat, Diana Mergenovna, 2016. Investigation Of Money Laundering Methods Through Cryptocurrency, Journal of Theoretical and Applied Information Technology 20th January 2016. Vol.83. No.2.

36. Sjahdeini, Sutan Remy, 2007. Seluk-Beluk Tindak Pidana Pencucian Uang dan PembiayaanTerorisme, Jakarta: Pustaka Utama Grafiti.

37. Sugiyono, 2011. Metode penelitian kuntitatif kualitatif dan R\&D. Alfabeta Bandung.

38. Suhariyanto, Budi, 2012. Tindak Pidana Teknologi Informasi (Cybercrime) Urgensi Pengaturan dan Celah Hukumnya, Jakarta: Raja Grafindo Persada.

39. Sutedi, Adrian, 2008. Pasar Modal Mengenal Nasabah Sebagai Pencegahan Pencucian Uang, Alfabeta, Bandung,

40. Tuanakotta, Theodorus M. 2013. Audit Berbasis ISA (International Standards on. Auditing). Jakarta: Salemba Empat.

41. Undang-Undang Republik Indonesia Nomor 8 Tahun 2010 Tentang Pencegahan dan Pemberantasan Tindak Pidana Pencucian Uang.

42. Undang-Undang Nomor 15 Tahun 2003 Tentang Penetapan Peraturan Pemerintah Pengganti Undang-Undang Nomor 1 Tahun 2002 Tentang Pemberantasan Tindak Pidana Terorisme, Menjadi Undang-Undang.

43. Walsh, Margaret. 2003. Teaching qualitativeanalysis using QSR NVivo. The QualitativeReport, Vol. 8, No. 2, pp. 251-256.

44. Widodo, 2013. Pemahaman tentang hukum pidana di bidang teknologi Informasi (cyberlaw), Yogyakarta,Aswaja Pressindo.

45. Yong-an, Zhang, 2016. Asia, International Drug Trafficking and US-China Counternarcotics Cooperation. dalam (http://www.brookings.edu/).

46. Zahudia Zalina Muhamed, 2016. Regulation of Virtual Currencies: Mitigating the Risks and Challenges Involved, Journal of Islamic Finance, Vol. 5 No. 1 (2016) 063 - 073.

47. United Nations of Drugs Crime, 2016. "Drug Trafficking", dalam (http://www.unodc.org/)

48. BNN, 2016. "Jalur Peredaran Gelap". dalam (http://www.bnn.go.id/). 